\title{
Jordanian Evidence on the Capital Structure
}

\author{
Imad Zeyad Ramadan ${ }^{1}$ \\ 1 Department of Finance, Applied Science Private University, Amman, Jordan \\ Correspondence: Imad Zeyad Ramadan, Full Prof., Department of Finance, Applied Science Private \\ University, P. O. Box 166, Amman, Jordan. E-mail: i_ramadan@asu.edu.jo
}

Received: April 27, 2016

doi:10.5539/mas.v10n10p208
Accepted: May 23, 2016

Online Published: July 27, 2016

URL: http://dx.doi.org/10.5539/mas.v10n10p208

\begin{abstract}
This study aims to identify the extent to which ownership structure and management efficiency affect capital structure in the Jordanian companies. The results show that the impact of institutional investors and the percentage of ownership of major shareholders are statistically significant and are among the determinants of the capital structure for the Jordanian companies. Also, the current study has concluded that the management efficiency has a statistically significant effect on capital structure of the Jordanian companies in general, and the return on total assets and return on equity are among the determinants of the capital structure for the Jordanian companies.
\end{abstract}

Keywords: ownership structure, management efficiency, capital structure, Jordan

\section{Introduction}

This study aims to add new evidence about the debate over the impact of the ownership structure and management efficiency on the capital structure of the Jordanian companies. Thus, the importance of this study stems from being that it adds new evidences on the impact of the ownership structure and management efficiency on the capital structure of the developing countries such as Jordan, where many of the available information on this relationship are experiences of developed countries like America and Europe, which are wholly different from the reality of the situation of developing countries. This makes the results of this study realistic for developing countries to contribute to a better understanding of the decision of corporate finance in developing countries, so this study is done to bridge the gap in this aspect.

The problem of the current study stems from the lack of clarity regarding the extent to which ownership structure and management efficiency affect the company's financing decision, where the current study aims at answering the following question: is there a relationship between company's ownership structure, its management efficiency and its financing decisions? So such financing decisions can be used to mitigate Agency Costs?

Accordingly: the null hypothesis which the study aims to examine can be formulated as follows:

$H_{0}$ : There is no statistically significant effect for ownership structure or management efficiency on capital structure in the Jordanian companies.

\section{Literature Review}

Zeckhauser \& Pound (1990) concluded no relationship between the ownership of major shareholders in ownership structure and capital structure, and there is a positive role for major shareholders in the control over the management in favor of the remaining shareholders. A study carried out by Fith (1995) has concluded that capital structure in the American companies is significantly affected by ownership structure as expressed by the power of the shareholders in the management.

Brailsford, et al. (2000) have concluded a statistically significant non-linear positive relationship between ownership structure and company's financing decision, where the ratio of borrowing financing increases based on management ownership ratio to a certain limit then debt starts to decrease.

It is worth noting that most of the studies on the relationship between ownership structure, capital structure and the company's performance were conducted on US companies, which are characterized by severe distribution in the structure of ownership compared to other countries, especially East Asian countries, while studies on companies in countries of East Asia such as the study Claessens et al. (2002) concluded that ownership of the families on the company's control causes a large concentration in the percentage of ownership of the 
management in East Asia, and as a result of this situation that the study showed a statistically significant positive correlation between the ownership structure and the proportion of debt because of the unwillingness of shareholders in mitigation of the proportion of their ownership. Also Anderson et al. (2003) concluded a study that showed a positive statistically significant relationship between ownership structure and capital structure in companies in East Asian countries. So that the greater concentration of ownership leads to increased reliance on external funding ratio due to external financing costs go down with concentration of ownership or with ownership of the family style. This study has attributed this result to the following: The families usually give great importance to their reputation, in addition to that the lending banks usually develops personal relationships with influential families over the years.

The high profitability and good performance corporates have better access to external financing, so a positive relationship is expected between the efficiency of the management and the proportion of debt in the capital structure. A study by Modigliani and Miller (1963) has concluded the managements of high efficiency in achieving profits can get external financing because of their ability to fulfill their borrowing and low risk obligations.

Therefore the study carried out by (M \& M, 1963) suggests a positive relationship between the efficiency of the management and the proportion of debt in the capital structure, in order to take advantage of the tax savings resulting from borrowing. But many studies have concluded that the relationship between the efficiency of the management and the proportion of debt is an inverse relationship, as the high-efficiency companies in achieving profits may not be in need of external financing due to the use of the company's internal sources in the process of expansion and growth. The study carried out by (Miller, 1977) and study (DeAngelo \& Masulis, 1980) and study (Titman \& Wessels, 1988) disagreed with the findings of (M \& M, 1963) study, it concluded that the companies can get the tax savings from sources other than borrowing, such as consumption, and that companies that achieve high profits working to use these profits to repay their debt, which results in a reduction in the debt ratio.

By contrast, a study such as (Long \& Malitz, 1985) and (Fith, 1995) did not find any evidence that the efficiency of management affects the structure of capital.

Fama and French (2002) and Wald (1999) have found that the efficiency of the administration is the most important factor in determining the structure of the capital, where they found a statistically significant inverse relationship between profitability and the proportion of debt in the structure of capital.

Rajan and Zingaless (1995) have found that the capital structure depends mainly on a set of the company's properties, including the efficiency of the administration, represented by its ability to achieve profit.

But the study carried out by (Berk, 2005), which aimed to study the effect of the efficiency of the administration in achieving earnings growth rate of future investment opportunities and tangible assets and the size of the company and the growth rate of the company and volatility in the company's revenue and tax shield to borrow on capital structure during the two periods 2000-2001 and 2002-2003 has found a statistically significant negative impact at the 0.05 level for the efficient administration of capital structure, during the first period, but during the second period, the study concluded that the intangible assets ratio is the only factor which has an impact on the capital structure, and that this negative effect was statistically significant at the level of 0.1 , and management efficiency has no statistically effect on capital structure.

\section{Methodology}

221 companies listed at Amman Stock Exchange were analyzed at the end of 2015, Multiple regression models at significance level 0.05 was used to examine the null hypothesis where the study model consisted of five independent variables to express ownership structure and management efficiency. The variables of the study were as follows:

\subsection{Debt Ratio}

The debt ratio expresses capital structure, which is the dependent variable in the study model, and there is more than one definition of debt ratio, where it can be defined as book value of long-term loans divided by the sum of the market value of equity and book value of long term loans (Titman \& Wessels 1988, Graham 1996). Long-term loans can also be used to reflect the debt ratio as in the study of (Miguel \& Pindad, 2001), but for the purposes of this study debt ratio was expressed as the ratio of total liabilities to others to total assets, where the use of this definition by virtue of the Jordanian financial disclosure instructions.

\subsection{Ownership Structure}

Ownership structure was expressed byfour independent variables in the study model: 
a) Institutional investors: Which is the ratio of total shares owned by institutions and companies to the capital paid for the company.

b) The ratio of possession of members of the board of directors: shares owned by the members of the board of directors to the capital paid to the company.

c) The ratio of major shareholders' possession: the ratio of shares owned by major shareholders to the company's paid capital where the Jordanian financial disclosure instructions consider major shareholders as those who have $5 \%$ or more from company's shares.

\subsection{Management Efficiency}

Management efficiency was expressed by profitability indicators:

a) The rate of return on total assets: this relationship is measured based on the operational profit and the size of assets, i.e., the extent to which the management is able to generate operating profits from the funds invested in the assets.

b) The rate of return on equity: this is measured by each Dinar invested by the ordinary shares where this ratio takes into account the effect of operating and financing activities

\section{The Model}

The study model can be written as follows:

\section{Capital Structure $=f($ Ownership Structure + Management Efficiency)}

Since we will express the capital structure by the debt ratio, and the ownership structure by institutional investors, the percentage of major shareholders and the percentage of Management ownership, and we will express management efficiency by rate of return on total assets and rate of return on equity, we can write the study model as follows:

\section{Capital Structure}

$$
\begin{aligned}
& =f(\text { Institutional Investors }+ \text { Owner Concentration }+ \text { Management Shareholder } \\
& + \text { Return on Assets }+ \text { Return on Equity) }
\end{aligned}
$$

The above equation can be written in a manner consistent with the multiple regression models as follows:

$$
\mathrm{C}_{-} \mathrm{S}_{\text {it }}=\alpha+\beta_{1} \mathrm{IN}_{-} \mathrm{IV}_{\mathrm{it}}+\beta_{2} \mathrm{O}_{-} \mathrm{C}_{\mathrm{it}}+\beta_{3} \mathrm{M}_{-} \mathrm{S}_{\text {it }}+\beta_{4} \mathrm{ROA}_{\mathrm{it}}+\beta_{5} \mathrm{ROE}_{\mathrm{it}}+\varepsilon
$$

Where: $C_{-} S$ is the capital structure of the company expressed as the debt ratio; $i$ and $t$ are the $i^{t h}$ cross-sectional firm at $t^{t \bar{h}}$ period ; $\alpha$ is a constant term; $\beta^{\prime s}$ are the slope coefficients to be estimated; IN_IV is the companies' Institutional Investorsratio; O_Cis the company's ownership concentration ratio expressed as the ratio of owners who own more than $7 \%$ of the paid up capital; M_Sis the ratio ofcapital owned by the management; ROA is the Return on Asset ratio; ROE is the return on Equity ratio and $\varepsilon$ is the random error.

\section{Test of Hypothesis}

The currents study aims to examine the null hypothesis which states that neither ownership structure nor management efficiency have statistical effect on capital structure of the Jordanian companies listed on Amman Stock Exchange. Multi regression and F test were used to test this hypothesis at the significance level 0.05 , where $\mathrm{F}$ test aims to identify the level of significance for the relationship between ownership structure and management efficiency and their effect on capital structure, where null hypothesis will be rejected in case Sig. of $\mathrm{F}$ test is higher than the desired level of significance 0.05 .

\section{Results}

The current study aimed at examining the effect of ownership structure and management efficiency on capital structure in the Jordanian companies. Three independent variables were used to express ownership structure, namely institutional investors, the percentage of major shareholders and the percentage of Management ownership, IN_IV, O_C and M_O, while two independent variables were used to express the management efficiency which is: $\mathrm{ROA}$ and $\mathrm{ROE}$. Study model was applied on all companies listed on Amman Stock Exchange at the end of 2015, the number of which is 233 companies divided into three main sectors: financial sector, service sector and industrial sector. 12 companies were excluded due to lack of information resulting in 221 companies for the population of the study.

Table 1 shows the results of multiple regression equation of the independent variables analyzed in the study model, which has been used to determine the effect of the ownership structure and management efficiency on 
capital composition. The table shows that there is a positive impact for both institutional investors and the proportion of ownership of major shareholders, as determinants of the ownership structure, on the capital structure of the Jordanian companies, as the table shows that the regression coefficients are 0.0389and 0.1133 respectively. Also the table shows that there is a negative impact of the ownership of the board of directors, as one of the determinants of ownership structure, on the capital structure of the Jordanian companies with a regression coefficient equal to -0.0871 .

As for the management efficiency, the results showed that there is a negative impact for both return on equity and return on total assets on the capital structure, and the regression coefficient for these two variables were $(0.7015)$ and $(0.7842)$ respectively. This result is consistent with the view that as the company's profitability increases, the dependence on financing by borrowing declines, and increased reliance on self-financing through profits.

Table 1. Multi-Regression Results

\begin{tabular}{ccccc}
\hline & Beta & Std. Error & t-value & Sig. \\
\hline (Constant) & & 2.9754 & 5.6464 & 0.000 \\
IN_IV & 0.0389 & 0.0617 & 2.124 & 0.0317 \\
O_C & 0.1133 & 0.0812 & 2.079 & 0.0427 \\
M-O & -0.0871 & 1.4251 & -1.5121 & 0.1139 \\
ROA & -0.7015 & 0.4037 & -9.258 & 0.000 \\
ROE & -0.7842 & 0.1117 & -11.147 & 0.000 \\
\hline
\end{tabular}

Dependent Variable: C_S

Using t-test to determine the statistical significance of the regression coefficients, we find that the value of Sig. for institutional investors ,the percentage of ownership of major shareholders and the percentage of ownership of the board members amounted to $0.0317,0.0427$ and 0.1139 respectively, which means, as for the ownership structure, the regression coefficients for each of the institutional ownership ratio and the percentage of ownership of major shareholders differ statistically from zero. Meaning that, the impact of institutional investors and the percentage of ownership of major shareholders are statistically significant and are among the determinants of the capital structure for the Jordanian companies.

With respect to management efficiency, the results show in Table 1 that the Sig. value for each of the return on total assets and return on equity is 0.000 , which means that the slope of the regression equation for the independent variables is statistically significantly different from zero, and that the impact of the management efficiency on the capital structure is statistically significant, andthe return on total assets and return on equity are among the determinants of the capital structure for the Jordanian companies.

Accordingly, the null hypothesis was rejected and the alternative hypothesis was accepted which states that ownership structure and management efficiency have a statistically significant impact on the Jordanian companies' capital structure.

\section{Acknowledgements}

The author is grateful to the Applied Science Private University, Amman, Jordan, for the financial support granted to this research project (Grant No. DRGS-2015-2016-52).

\section{References}

Anderson, R. C., Sattar., M. A., \& Reeb, D. M. (2003). Founding family ownership and the agency cost od debt. Journal of Financial Economics, 68, 263-285. http://dx.doi.org/10.1016/S0304-405X(03)00067-9

Berk, A. (2005). Drivers of Leverage in Slovenian Blue-Chip Firms and Stock Performance Following Substantial Debt Increases. Working Paper, (172). University of Ljubljana, Faculty of Economics. Retrieved form http://papers.ssrn.com/sol3/papers.cfm?id=1013085

Brailsford, T. J., Oliver, B. R., \& Pua, S. H. (2000). Theory and Evidence on the Relationship between Ownership Structure and Capital Structure. Retrieved form http://economic.anu.eduau/research/papers/pdf/f9901-pdf

Claessens, S. S., Djankov, J., Fan, P. H., \& Lang, L. H. P. (2002). Disentangling the incentive and Entrenchment Effects of Larg Shareolding. Journal of Finance, 57, 2741-2771. http://dx.doi.org/10.1111/1540-6261.00511

DeAngelo, H., \& Masulis, R. (1980). Optimal Capital Structure under Corporate and Personal Taxation. Journal of 
Financial Economics, 8, 3-29. http://dx.doi.org/10.1016/0304-405X(80)90019-7

Fama, E. F., \& French, K. R. (2002). Testing tradeoff and pecking order predictions about dividends and debt. The Review of Financial Studies, 15, 1-33. http://dx.doi.org/10.1093/rfs/15.1.1

Fith, M. (1995). The Impact of Institntional Stockholders and Managerial Interest on the Capital Structure of Firms. Managerial and Decision Economics, 16, 167-175. http://dx.doi.org/10.1002/mde.4090160207

Long, M., \& Malitz, I. (1998) The Investment-Financing Nexus: Some Empirical Evidence. Midland Corporate Financial Journal, 3, 53-59.

Miller, M. (1977). Debt and Taxes. Journalof Finance, 32, 261-275. http://dx.doi.org/10.2307/2326758

Modigliani, F., \& Miller, M. (1963). The Corporate Income Taxes and the Cost of Capital: A Correlation. American Economic Review, 53, 433-443.

Rajan, R. G., \& Zingales, L. (1995). What do we know about capital structure? Some evidence from international data. Journal of Finance, 50, 1421-1460. http://dx.doi.org/10.1111/j.1540-6261.1995.tb05184.x

Titman, Sheridan, \& Wessels, R. (1988) The Determinations of capital structure choice. Journal of Finance, 43, 1-19. http://dx.doi.org/10.1111/j.1540-6261.1988.tb02585.x

Wald, J. K. (1999). How firm characteristics affect capital structure: An international comparison. Journal of Financial Research, 22, 161-87. http://dx.doi.org/10.1111/j.1475-6803.1999.tb00721.x

Zeckhauser, R. J., \& Pound, J. (1990). Are large shereholders effective monitors? An investigation of Share ownership and corporate performance. In R. G. Hubbard (Ed.). Asymmetric Information, Corporate Finance and Investment, University of Chicago Press, 149-180.

\section{Copyrights}

Copyright for this article is retained by the author(s), with first publication rights granted to the journal.

This is an open-access article distributed under the terms and conditions of the Creative Commons Attribution license (http://creativecommons.org/licenses/by/4.0/). 